\title{
Mixed Method: Students' Ability in Applying Writing Mechanics in Analytical Exposition Text
}

\author{
M. Fadhly Farhy Abbas ${ }^{1)}$, Nabila Firda Asy'ari ${ }^{2)}$ \\ ${ }^{1}$ Universitas Lancang Kuning \\ email:fadhly@unilak.ac.id \\ ${ }^{2}$ Universitas Lancang Kuning \\ email:nabilaafirda@yahoo.com
}

\begin{abstract}
Based on the English syllabus of SMA Serirama YLPI Pekanbaru, the students should be able to write in English by paying attention to the linguistics elements. One of them is the use of writing mechanics. This study aimed at investigating students' ability in applying writing mechanics in Analytical Exposition texts and explained the factors that influence students' ability in applying writing mechanics in the eleventh grade of SMA Serirama YLPI Pekanbaru. The design of this research was mixed method. The population of this research was all the eleventh grade students of SMA Serirama YLPI Pekanbaru with total of 41 students. Sampling technique used in this research was total sampling. The instruments used were test and interview. Based on the result of the test, the average score of students' ability in applying writing mechanics in an Analytical Exposition text was 71,56. Moreover, based on the interview result, the factors that influence the students' ability in applying writing mechanics were the students lack of motivation to open dictionary to find the correct spelling of words, the difference between the pronunciation and written of words make students confused, and lack of student knowledge about writing mechanics. In conclusion, the students' ability in applying writing mechanics in an Analytical Exposition text at the eleventh grade of SMA Serirama YLPI Pekanbaru is categorized into fair level caused by several factors.
\end{abstract}

Keywords: Analytical exposition text, writing mechanics, ability 


\section{INTRODUCTION}

Writing is one of the four language skills that should be mastered by the students. By writing, writers are able to deliver and share their thoughts with everyone. In writing, there are several aspects to make the paragraph is accepted as a good paragraph. They are content, organization, vocabulary, grammar, and mechanics. Here, the mechanics of writing are spelling, capitalization, and punctuation.

In English, a word could have a similar spelling one another. This similarity makes the reader from nonnative English speaker usually misunderstand the meaning of a paragraph that the writer wants to deliver because the writer does not use correct word spelling. when, the use of capitalization which relates to the use of punctuation.

Capitalization is usually used with punctuation to help the reader easy to read the passage. Basically, the use of punctuation can help the reader to indicate where is the place that they should rise or fall the tone even to indicate the place to pause. Using a punctuation in a wrong place can make the reader confuse and difficult to get the meaning of a paragraph. Also, by using correct and proper punctuation in our paragraph can make the paragraph clear, understandable, and easy to read. Furthermore, by using punctuation the relationships between words and clauses can be easily read by the reader.

Pertaining to the English syllabus at grade eleventh of SMA Serirama YLPI Pekanbaru, it claims that the students should be able to write in English by paying attention to the social function, structure, and the linguistic elements correctly and appropriate to the context. One kind of the linguistics elements that the students should understand and able to use is the use of writing mechanics. The students are expected to apply correct and appropriate writing mechanics in order to make the paragraph good and lead the readers to not misunderstand the purpose of the text.

Considering with the syllabus and the researcher's observation, the researcher is interested to investigate the students' ability in writing skill especially their ability in using writing mechanics to make a good text. Also, the researcher wanted to know the factors influence the students' ability in applying writing mechanics. Hopefully, this research could be a source to the next or future researchers.

\section{Writing}

Writing is a productive skill where everyone is able to deliver and share the idea in a written product. By doing so, the readers from anywhere will be able to get the idea. According to some experts, writing has many definitions. First, according to Gillett et al (2009) stated that "writing is one of the main ways that human beings communicate: it is a social practice". The statement could be explained that writing is always used in daily life to communicate with others for instances, writing a message, writing ideas to be shared, and making a job application. In addition, Kane (2000) states that there were two broad assumptions of writing. First, writing is a rational activity. It means that the writer does not need to be a genius to write clear, effective English. The writer only needs to understand the aspects that need to be including in a paragraph. Second, writing is worth learning. The meaning of the second assumption is that writing can be a useful skill used to get a job or career. Nowadays, there are many profesion that use writing such as a novelist, a poet, or a journalist. We can be someone who is popular around the society and we got pay too. Then, Abbas and Dwita (2019) stated that writing is 
an action to make a records or data on middle by means of a script. Based on the definitions above, writing can be said as an activity to share ideas by arranging the words into a sentence and become a paragraph in written form and it is always used in human's daily life to communicate with others in written form. Also, writing is a useful skill because by writing something, the writers are able to earn money and it could be said as a job.

There are many rules that learners need to understand and master the writing skill. It makes writing skill become one of the hardest skills in English and makes the learners afraid to start to write even though there are many advantages by writing something. For example, by writing a story we can express our feelings on it and also it can earn money depends on the writer's aim in writing. Basically, there are some purposes of writing such as to entertain the reader, to persuade the reader, even to inform something to the reader depending on the writer.

\section{Mechanics in Writing}

To construct a good text and acceptable to the readers, there are many rules that the writer needs to do while writing. The ability to arrange the words become a sentence then arrange it to a paragraph is not an easy job. At least, there are five components that will be assessed in a writing namely content, organization, grammar, vocabulary, and mechanics. According to Kane (2000), "Mechanics refers to the appearance of words, to how they are spelt or arranged on paper". Mechanics in writing a paragraph includes spelling, capitalization, and punctuation.

The rules gathered under mechanics attempt to make writing consistent and clear. Sometimes, newbie writer ignores to give their attention to the writing mechanics in their writings.
Whereas without appropriate spelling, appropriate capital letter, and appropriate punctuation marks in writing can make the readers misunderstand to the actual point that the writer wants to deliver. Then, it will make the readers think the story that made by the writer is not good enough to be read because the writing is not well-written. That is why the writing mechanics is important and should not be ignored by the writer. The use of good mechanics is one aspect that makes a text can be said as a perfect text. By having a good mechanics in writing, it will help the reader to easy to read and it will attract more readers.

\section{Spelling in Writing}

Spelling is included into writing mechanics. In Oxford Dictionary (2008), Spelling comes from a word 'spell' means the ability to say or write the letters of a word in the correct order. Spelling is an essential component of a success writing. Spelling, writing, and reading is related term each other. Having perfect spelling in writing is a plus point in writing skill. It is because of the correct spelling uses in the writing will help the reader to not face the difficulties and misunderstandings while reading the text. By revising the writing constantly, the writer's ability on using correct spelling will improve. It also obtains to the students who are facing the difficulties in writing. According to Ehri in Kane (2000), having accurate spelling may reflect the others linguistics knowledge like phonology and morphology knowledge. Good spelling occurs if the writer has good sense in phonology. It is because the similar sounds made by English word often made the writer especially form a non-native English country confuse to write them. Johnson in Said (2018) mentions that "spelling as the act of recognizing or mimicking a word in its correct sequence of letters in either oral or written form, 
taking into consideration the crucial integration of both phonological and alphabetic skills". Cook in Subhi and Yasin (2015) stated that students who are not a native speaker of English will be easier to face the difficulties of using the correct spelling of English words because the non-native speaker students do not know the actual system of English words and it caused the appearing of the use of wrong letter. Usually, the errors that the learners did are:

1] Omission (the deletions of some letters).

2] Substitutions (replacing one letter to another letter).

3] Insertion (adding an extra letter in a word).

4] Transposition (reversing the position of a letter from a word).

\section{Capitalization in Writing}

In Oxford Dictionary (2008), capitalization comes from the word 'capitalize' which means write a letter of the alphabet as a capital. The capital letter is used at the beginning of a word. It is to show the readers the actual meaning that the writer wants to deliver and facilitate the reader to indicate the changing of the meaning in the paragraph. By using the capital letter in the first letter of a word indicating a new sentence has begun. According to Riyanto (2013), there are some uses of capital letters as follows:

1. Used in the first sentence, for instance:

1) Football is very popular in the world.

2) Used for the first letter in the name of country, nationality, language, religion, person's name, place, event, trademark, title, for instance:
a. Indonesia
b. English
c. Catholic
d. Jennifer
e. London
f. Jakarta Trade Expo
g. Nokia
h. Mr./Mrs.
i. M.Ed/ Dr/ Ph.D

3) Used for the title of a book, film, etcetera, for instance:
a. The Adventure of Tom Sawyer
b. Terminator

Pertaining to the above explanation, there is one thing that the capitalization system has and able to say as a unique thing. In the English capitalization system, the single letter which indicates a subject ' $I$ ' always written by using the capital letter. . But in contrast, it does not occur to the other form of ' $I$ ' such as 'me', 'my', and 'mine'. Then, it also does not occur to the other subject like 'you', 'we', and the others. They only will be capitalized when they are in the title or at the beginning of a sentence.

\section{Punctuation in Writing}

Punctuation marks help to convey the precise meaning of a sentence and it also able to change the meaning. The use of punctuation marks cannot be neglected because the use of inappropriate punctuation marks in writing can affect the meaning that writer wants to convey. Shweba and Mujiyanto (2017) stated in their research paper that punctuation marks have been used to prevent miscomprehension of the written language. In addition, punctuation marks help the writer to create the rhythm in reading the text. Punctuation marks are only used in a written communication. It is easier the reader to get points of what the writer wants to share. Punctuation also indicates the place to pause, stop, even indicates the place to rising and falling the intonation while reading the writing. Kane (2000) states that "to write well, the writer should punctuate well; 
but to punctuate well, the writer should write well". It means that by always revising a text, the writer will able and become familiar with the punctuation marks that should be used. As the result, the text made the writer can be said as a good text. There are many kinds of punctuation mark and also the purpose of it. The examples of punctuation marks such as comma, period, and question mark. There are some punctuation marks as stated by Riyanto (2013) as follows:

1] Period (.)

It is used to end the sentence and after the abbreviation.

2] Question Mark (?)

It is used after a question/direct question.

3] Exclamation Mark (!)

It is used to express surprised, amazed, shock. Also, it is used to indicate a loud voice.

4] Comma (,)

It is used between things in a list, when need additional information, and it is used to indicate pause from a long sentence.

5] Semi-colon (;)

It is used to separate two parts of a sentence.

6] Colon (:)

It is used to deliver a list or a quote in a sentence.

7] Apostrophe (')

It is used for an omitted letter and to indicate possession.

8] Quotation Mark (“....”)

It is used for a direct sentence and to indicate that the other person writes the sentence.

\section{Analytical Exposition Text}

There are many types of text according to the purpose in English such as descriptive text to describe a thing, narrative text to entertain the reader, and exposition text to persuade the reader. According to Djuharia in Amilia and Susbiyanto (2016) defined "analytical exposition as argumentative text because writer providing readers or listeners with a point of view, ideas, or thoughts of topic or issue or problem needs to get attention or explanation with no appeared efforts to persuade readers". In addition, Kane (2000), exposition is constructed logically and it deals with facts, ideas, and beliefs. Supporting the statements from Kane, Untoro (2016) states that "the topic should be related to the recent and important problems happen and need to be explored". Thus, analytical exposition text is a text which tells about the writers' arguments about an issue in social life to persuade the readers or the listeners. Also, we can say that analytical exposition text is a text which elaborates the idea from the writer about an issue happened in the society. This text purposes to persuade the readers to give attention to the issue, in the other words, the writer wants to persuade and tell the readers that the issue is an important matter. Eventhough analytical exposition text wants to persuade the readers, this text does not give any suggestions to do something to the issue. This text does not give sollution to prevent a bad effect made by the issue. Usually, analytical exposition text tells a phenomenon that currently happening in society such as global warming issue, transportation issue, and education related issue.

Writing a text in English should be followed by the appropriate generic structures and language features. Every text uses different generic structure and language features. According to Mulya in Elita (2017), the generic structure of analytical exposition text are thesis statement; introduce the topic and indicate the main point of view that the writer wants to share. Arguments; explain the writer's arguments to support the thesis statement. The number of argument paragraph could be varied yet the argument should be supported by 
evidence and explanation. Reiteration; restate and conclude the writer's point of view to make the thesis statement stronger.

The language features of analytical exposition text that are stated by Sudarwaty and Grace in Elita (2017) are: using mental verbs to express opinions, using linking word to connect the arguments (Firstly, Secondly, Next), using simple present tense, using compound and complex sentence, using modal and adverb, and focusing on generic human and non-human participant.

\section{METHOD}

The design of this research was mixed method. According to Creswell (2012), mixed method research design is a procedure for collecting, analyzing, and "mixing" both quantitative and qualitative methods in a single study or a series of studies to understand a research problem (Creswell \& Plano Clark, 2011). In this researcher, the researcher used explanatory sequential mixed methods design (also called a two-phase model). According to Creswell (2012), this design consists of collecting quantitative first and qualitative data then to help explain or elaborate on the quantitative results. The population of this research were all the students at the eleventh grade of SMA Serirama YLPI Pekanbaru. Total sampling was used by the researcher as the sampling technique. The total of the samples in this research as follows.

Table 1. The Sample of the Research

\begin{tabular}{ccc}
\hline No. & \multicolumn{1}{c}{ Grade } & Learners \\
\hline 1. & XI Social & 21 \\
2. & XI Science & 20 \\
& Total & 41 learners \\
\hline
\end{tabular}

There were two kinds of data in this research, they are: quantitative and qualitative data. In collecting quantitative data, the researcher used a written test to collect the data from the participants. Here, the researcher gave the students two error texts of Analytical Exposition text. Then, the students were asked to correct the text by using appropriate writing mechanics. The text consisted of 17 errors of spelling, 16 errors of capitalization, and 17 errors of punctuation with score per each correct answer were 2 . The students had 90 minutes to finish it. After that, the researcher collected the students' work. Finally, the students' works were analyzed by the researcher. In collecting qualitative data, the researcher used semistructured interview. According to Sugiyono (2015), the aim of semistructured interview is to find out the problem more openly, where the parties invited to interview are asked for their opinions and ideas. The researcher interviewed the students of the eleventh grade randomly. The researcher asked some questions to the students related to the use of writing mechanics. In order to analyze the quantitative data, the researcher used the scoring rubric as shown in the Table 2 below.

Table 2. Rubric of Scores

\begin{tabular}{|c|}
\hline 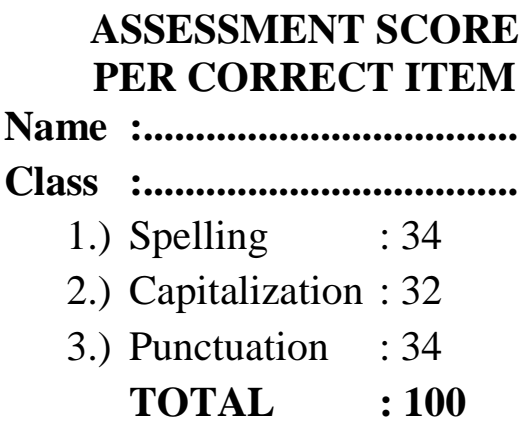 \\
\hline
\end{tabular}

Then, it was analyzed using descriptive statistics formula. According to Siregar (2014), the purpose of using descriptive statistics to analyze the data is to get a general representation about the data which is being measured. Moreover to analyze the qualitative data, the 
researcher transcribed the interview and explain the factors influencing the students' ability in applying writing mechanincs.

\section{FINDINGS AND DISCUSSION}

This chapter presents the findings of this research. It presents the answer of research question, they are "How is the students' ability in applying writing mechanics in Analytical Exposition text at the eleventh grade of SMA Serirama YLPI Pekanbaru?" This question is answered based on the data obtained from the test. Meanwhile, for the second resarch question "What factor influencing the students' ability in applying writing mechanics in Analytical Exposition text at the eleventh grade of SMA Serirama YLPI Pekanbaru?" is answered by the interview result.

In order to answer this question, the researcher gave the error texts test to the sample of this research. The test consists of two texts which contains 17 errors of spelling, 16 errors of capitalization, and 17 errors of punctuation with the total errors of 50 . After giving the test, the researcher calculated the score from the test. Based on the test result, it showed that there were two students who got 94 and two students got 92. So that, there were four students categorized into excellent. Then, there were three students who got 86 , one student got 82 , and five students got 80 . So, there were nine students were on good category. Next, there were one student who got 78 , four students who got 76, three students got 74, three students got 72 , two students got 70 , one student got 68 , two student got 66 , two students got 64, two students got 62, and two students got 60 . So, there were 22 students were on fair category. Last, there were two students who got 56, two students got 52 , one student got 40 , and one student got 34 . So that, there were 6 students on failed category.
In accordance with the data gained in this study, it can be stated that the students' score in applying writing mechanics was categorized into Fair. It was because the students' mean score was 71,56. For further information, the students' score obtained from the test can be seen at the Table 3 below.

\section{Table 3. The Percentage of the}

Students' Ability in Applying Writing Mechanics

\begin{tabular}{cccc}
\hline Scale & Category & $\begin{array}{c}\text { Frequenc } \\
\text { y }\end{array}$ & Percentage \\
\hline $90-100$ & Excellent & 4 & $9,76 \%$ \\
$80-89$ & Good & 9 & $21,95 \%$ \\
$60-79$ & Fair & 22 & $53,66 \%$ \\
$<60$ & Failed & 6 & $14,63 \%$ \\
\hline
\end{tabular}

From the Table 3, it shows that $9,76 \%$ of the students were categorized into excellent. There were $21,95 \%$ students were categorized into good. $53,66 \%$ of the students were categorized into fair. $14,63 \%$ of the students were in failed category. By considering the students' average or mean score, the students' ability in applying writing mechanics in Analytical Exposition text at the eleventh grade of SMA Serirama YLPI Pekanbaru was in fair category. The data on the table 3 could be presented in the following diagram.

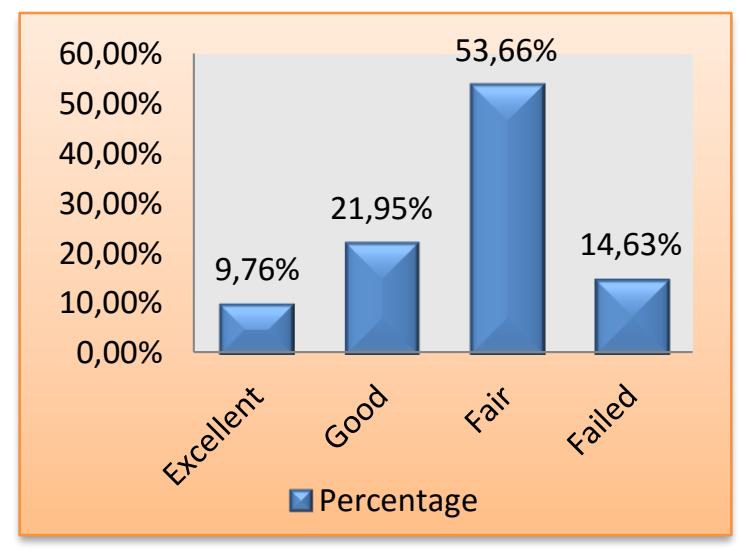
Diagram 1. The Categories of the Students' Ability in Applying Writing Mechanics in Analytical Exposition Text


The second question is "What factor influence the students' ability in applying writing mechanics in Analytical Exposition text at the eleventh grade of SMA Serirama YLPI Pekanbaru?" In order to answer this question, the researcher done the interview to some of the samples. Here, the researcher used semistructure interview to find out the problem more openly, where the parties invited to interview were asked for their opinions and ideas. The researcher interviewed the students of the eleventh grade randomly. The researcher asked some questions to the students related to the use of writing mechanics. The instrument namely interview was done by the researcher to collect the qualitative data.

From the interview, the researcher found that almost all of the students do not know what writing mechanics is. The students never heard that before the researcher did the research there. In the other hand, they were familiar with spelling, punctuation, and capitalization. The students stated that their teacher never teach them writing mechanics. Most of them know the use of some punctuation for example the use of period, comma, question mark, and exclamation mark. They stated that period is used in the end of a sentence and to indicate stop while reading. Then, they stated that comma is used to indicate pause while reading. After that, they stated that question mark is used to indicate a question and is used when someone wants to ask a question. Last, they stated that exclamation mark is used to indicate a command sentence and someone should do the command. The students also knew what capitalization is. They stated that capitalization is the use of capital letter in a word. they also knew where to use the capital letter. First, they stated that the capital letter is used in the first word in the sentence and after period. Then, capital letter is used in the first letter of person's name, the name of location for instance country, city, street, and lake. One of them also stated that capital letter is used in the abbreviation of word. The interesting thing when the researcher interviewed the students was they were lazy to check their spelling when writing the text. They were only focused to the content of the text. They also stated that checking the correct spelling on dictionary would waste their time. Some of them also stated that spelling is too difficult so that they ignored the use of it. In the other hand, some of them still concerned about their ability in applying writing mechanics because it would make their writing score higher. The students stated that they usually found the difficulties when using appropriate punctuation, spelling, and capitalization. In term of punctuation, they found difficult to differentiate where to use period and where to use comma. They also stated that, they should translate the text first before putting the appropriate punctuation in their text. They also found difficult to determine the appropriate punctuation to use in a running sentence. In term of spelling, they lacked of motivation to check the correct spelling on the dictionary. It was because of the pronunciation and the written form of a word in English was different and some of the words were similar, they were lazy to check it on the dictionary. They felt that it would waste their time. In term of capitalization, most of the students did not find any difficulties in applying correct capitalization. However, some of them felt confuse to apply it. It was because they only knew that capital letter was used in the first letter of word in a sentence.

Due to the purposes of this research to give information for the English teacher at SMA Serirama YLPI Pekanbaru to evaluate the students' 
ability in applying writing mechanics in analytical Exposition text. Hopefully, the findings of this research are able to develop the students's achievement in learning English especially of using writing mechanics. By looking at the findings, the mean score of the students' ability in apply writing mechanics is 71,56. In the other words, the students' ability in applying writing mechanics is on fair category.

The mechanics of writing is one of the components in aspects of a good writing. Even though the score of assessment of writing mechanics is lower than the other aspects such as content, organization, grammar and vocabulary, the use of writing mechanics cannot be neglected by the learners. Therefore, many researchers interested to do a research related to the writing mechanics problem occurred in students' writing ability.

Referring to the previous research from Dadzie and Bosiwah (2015), they stated that the students did not care and ignore the correct spelling. They had low level of performance in spelling to reasons such as ignorance, false analogy, and carelessness. The students of the eleventh garde of SMA Serirama also did not care and ignore the use of correct spelling. They were lazy to check the correct spelling on the dictionary. Most of the students did errors in term of omission, addition, and subtitution. However, the most errors done by the students was omission. They like to omit a letter in a word. Then, refers to the previous research by Abbas (2018), he found that the mean score of the students was categorized into fair level and he interviewed some of the students and found that the students had low motivation to write and had low alertness and carefulness. The students of the eleventh grade of SMA Serirama YLPI Pekanbaru also showed the same things.
They were categorized into fair level and they had low motivation to write.

Referring to Etinurwati (2016) in her research paper, she found that almost all of the students did not use the capital letter at the first letter in a sentence. Also, the students did not put the period at the end of a sentence in their writing. She assumed that most of the students were not paying attention to the use of punctuation, they only focused on the writing form. Not really different to the students' of SMA Serirama YLPI Pekanbaru, they were not paying attention to the use of punctuation and only focus on the writing organization. Fortunately, most of the students knew they should put capital letter on the first word of a paragraph after period.

Referring to Shweba and Mujiyanto (2017) stated that the cause of the students' errors in writing mechanics where: lack of knowledge, lack of balance in the curriculum, lack of intensive practice and experience, the influence from the mother tongue, overgeneralization of the rules and lack of exposure to the target language as it is used by its native speaker. In contrast, despite of the other errors made by the students of SMA Serirama YLPI Pekanbaru, the researcher realized that the curriculum did not provide the writing mechanics material. It just tells the students to apply correct and appropriate writing mechanics without telling any rules of how to apply it on the paragraph.

In relation to the above statements, Said (2018) found on his research that a poor practice for spelling and punctuation occurred in the school where he had done the reasearch. In addition, he stated that there were no additional strategies which could enhance the learners' skill and knowledge in spelling and punctuation marks, or help the instructor in order to avoid as well as minimalize the learners' error in their 
learning. Compared to SMA Serirama YLPI Pekanbaru, same as the previous research, the teacher did not use any spesific strategy to teach writing mechanics to the students.

By looking at all the previous researches done by the other researchers, it showed that the findings from this research and the findings from all of the previous researches of the similar topic was not significantly different. The students still had low motivation to write correctly and the students had low alertness and carefulness in writing. It also showed that the students were in fair level category.

In accordance with the findings of this research, there were some strenghts and weaknesses of this research that can be highlighted. The strenghts of this research were: it could show the students ability in applying writing mechanics in writing analytical exposition text, it could be a feedback for the teacher to teach the students all aspects of writing, and the teacher could evaluate her teaching strategy in the classroom.

In relation to the strengths above, this research also has some weaknesses. The weaknesses of this research are this research only showed the students' ability in applying writing mechanics, the teacher gives less time to the students to practice to write, and this research did not give the strategy to teacher to teach writing mechanics efficiently.

\section{CONCLUSION}

Based on the research conducted at the eleventh grade students of SMA Serirama YLPI Pekanbaru, researcher concluded that the students' ability in applying writing mechanics of the eleventh grade students of SMA Serirama YLPI Pekanbaru was categorized into Fair. Also, Researcher found that there are some factors influences the students' ability in applying writing mechanics in Analytical
Exposition text, for instances: the students are lack of motivation to open dictionary in order to check their spelling whether it is correct or not, the pronunciation and the written form of English word that different makes the students confuse to write the correct spelling of a word, the students are lack of knowledge. Most of the students only know the basic usage of capitalization and punctuation while writing a text, and the teacher never tells the students what writing mechanics is.

Concerning the above conclusions, it was necessary for the researcher to give some suggestions as follows: a.) The students of SMA Serirama YLPI Pekanbaru are expected to increase their knowledge, especially in applying writing mechanics when write a text. b.) The teacher should concern to teach the students all aspects of writing. c.) The teacher should give more time to the students to practice in analyzing writing mechanics when writing. d.) The English teacher should be creative and find out interesting strategy to increase students' ability in applying writing mechanics in Analytical Exposition text. e.) It is better for the next researchers to follow up and take some references in this research to be used in their research. Hopefully, the next researcher could conduct the other types of research to follow up the findings from this research. For instances, Classroom Action Research, Experimental Research, and Research and Development (R\&D).

\section{REFERENCES}

Abbas, M.F.F., \& Herdi, H. (2018). Investigating EFL Learners' Ability In Applying Writing Mechanics In An Argumentative Essay. Proceedings of ISELT FBS Universitas Negeri Padang, 6, 4550. 
Abbas, M. F. F., \& Dwita, S. E. (2019). Solving The Students'problem In Writing Descriptive Text Through Attribute Charts Strategy. Lectura: Jurnal Pendidikan, 10(1), 95-106.

Amilia, I.K., \& Sisbiyanto, A. (2016). The Effectiveness Of Send A Problem Technique For Teaching Writing An Analytical Exposition Text (A Quasi-Experimental Study of the Eleventh Grade Students of SMA N 8 Semarang in the Academic Year 2015/2016). In ELT Forum: Journal of English Language Teaching (Vol. 5, No. 2).

Creswell, John W. 2012. Educational Research: Planning, Conducting, and Evaluating Quantitative and Qualitative Research Fourth Ed. Pearson: Boston.

Dadzie, G., \& Lawrence, B. (2015). Spelling Errors Among Junior High School Students in the Cape Coast Metropolis. Journal of Language, Linguistics and Literature American Institute of Science Vol. 1, No. 3, 2015, pp. 46-54.

Elita, Y. 2017. Teaching Reading Analytical Exposition Text by Using Questioning The Author (QtA) Strategy to The Eleventh Grade Students of SMA N 11 Palembang. Thesis. State Islamic University Raden Fatah Palembang.

Etinurwati, D.A. (2016). An Analysis of Students' Ability in Using Punctuation in Descriptive Paragraph Writing at the First Semester of the Eighth Grade of SMPN 2 Pardasuka in the Academic Year of 2016/2017. Thesis. State Institute of Islamic Studies Raden Intan Lampung.
Gillett, A., Angela, H., \& Mary, M. 2009. Successful Academic Writing. Pearson Education: England.

Kane, T.S. 2000. The Oxford Essential Guide to Writing. Berkley Publishing Group: New York.

Oxford Dictionary. 2008. Learner's Pocket Dictionary: Fourth Edition. Oxford University Press.

Riyanto, S. 2013. The 1st Student's Choice. Complete English Grammar. Tata Bahasa Lengkap. Penerbit Andi: Yogyakarta.

Said, I.S. (2018). Difficulties Faced by Ninth Grade EFL Students When Practicing Writing Skills: Spelling and Punctuation Marks. Thesis. Middle East University.

Shweba, A.A.A., \& Mujiyanto, Y. (2017). Errors of Spelling, Capitalization, and Punctuation Marks in Writing Encountered by First Year College Students in AlMerghib University Libya. English Education Journal. 7(2), 93-103.

Siregar, S. (2014). Statistik Parametrik untuk Penelitian Kuantitatif Dilengkapi dengan Perhitungan Manual dan Aplikasi SPSS Versi 17. Bumi Aksara: Jakarta.

Subhi, S.N., \& Yasin, M.S.M. (2015). Investigating Study of an English Spelling Errors: A Sample of Iraqi students in Malaysia. International Journal of Education and Research. 3(6), 235-246.

Sugiyono. 2015. Metode Penelitian Kuantitatif, Kualitatif, dan $R \& D$. CV. Alfabeta: Bandung.

Untoro, B. (2016). The Effect of Group Investigation and Learning Style on Students' Writing of Analytical Exposition. IJEE (Indonesian Journal of English Education). 3(1), 29-45. 